\title{
A new species of Uusitaloia Marusik, Koponen \& Danilov (Araneae: Linyphiidae: Erigoninae), a genus thought to be monotypic, from the Wrangel Island, NE Russia
}

\section{Yuri M. Marusik \& Seppo Koponen}

\begin{abstract}
Marusik, Yu. M. \& Koponen, S. 2009: Anew species of Uusitaloia Marusik, Koponen \& Danilov (Araneae: Linyphiidae: Erigoninae), a genus thought to be monotypic, from the Wrangel Island, NE Russia. — Entomol. Fennica 20: 18 21.

A new species, Uusitaloia wrangeliana sp. $\mathrm{n}$. is described on the basis of two males from the arctic Wrangel Island, NE Russia. The type species of the genus, which has been thought to be monotypic, U. transbaicalica Marusik, Koponen \& Danilov, 2001 is redescribed. The position of the genus within its subfamily is also briefly discussed.

Yu. M. Marusik, Institute for Biological Problems of the North, IBPN, RAS, Portovaya Str.18, Magadan 685000 Russia; E-mail: yurmar@mail.ru

S. Koponen, Zoological Museum, University of Turku, FI-20014 Turku, Finland; E-mail:sepkopo@utu.fi
\end{abstract}

Received 10 October 2007, accepted 5 December 2007

\section{Introduction}

Spiders of the Arctic islands are rather well known due to numerous taxonomic and faunistic publications. Wrangel Island is the second in species richness among arctic islands, with about 45 reported species (Marusik \& Koponen 2006). Its spider fauna has been surveyed in several works (Khrulyova 1987, Marusik et al. 1992, Stishov 2004). Nevertheless, material collected on this island in 2006 revealed several additional species including an undescribed one, belonging to the erigonine genus Uusitaloia Marusik, Koponen \& Danilov, 2001. This genus was thought to be monotypic (see Platnick 2007). The type species, U. transbaicalica Marusik, Koponen \& Danilov, 2001, was described from the Barguzin mountain range, northeastern Buryatia, Transbaikalia. A single male (the holotype) was collected from mountain tundra. Wrangel Island, where the new species was collected, lies $3600 \mathrm{~km}$ northeast of the Barguzin range. In this paper we describe the new species and redescribe the type species of the genus, $U$. transbaicalica.

The type material of the new species is deposited in the Zoological Museum, Moscow Lomonosov State University (ZMMU) and the holotype of $U$. transbaicalica in the Zoological Museum, University of Turku (ZMUT).

\section{Species of Uusitaloia}

\subsection{Uusitaloia wrangeliana sp. $\mathrm{n}$.}

(Figs. 1a-b, 2d-e)

Type material. Holotype male in ZMMU with label "NE Russia, Wrangel Isl., upper flow of Neizvestnaya River, $71^{\circ} \quad 12.933^{\prime} \mathrm{N}, \quad 179^{\circ}$ 19,353'W, 128 m, steppe-like mound \#2, July 6- 
Fig. 1. Uusitaloia wrangeliana sp.n., holotype (a-b) and $U$. transbaicalica, holotype (c-e). - a, c. Left male palp, retrolateral view. - b, e. Tibia, dorsal view. - d. Terminal part of bulb, retrolateral view. Scale $=0.1 \mathrm{~mm}$. Abbreviations: Ea: embolic apophysis, Em: embolus, Ma: median suprategular apophysis, Me: embolic membrane, Sa: suprategular apophysis.

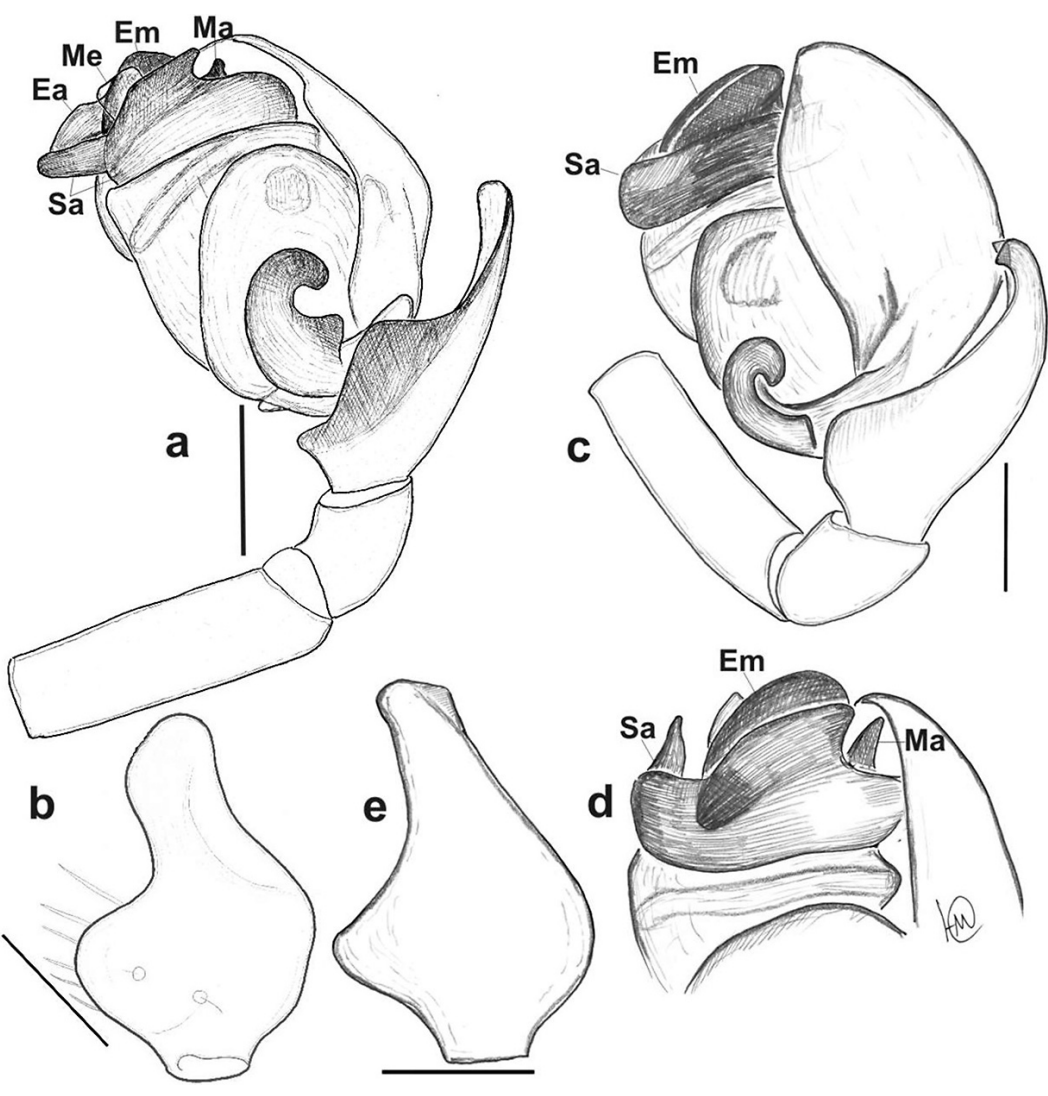

August 3, 2006 (O.A. Khrulyova)" and male paratype with same geographical label, steppe-like mound \#3, 3.VII.-3.VIII.2006.

Description. Male. Total length: 1.79 (All measurements are given in $\mathrm{mm}$ ). Carapace elongate (Fig. 2e): 0.71 long, 0.52 wide, length/width ratio $=1.37$. Body brownish, legs lighter. Carapace with pattern (Fig. 2e): dark spot in center and radial stripes. Chelicera with distinct stridulatory field covering about $2 / 3$ of lateral surface, 5 large promarginal teeth and 3-4 fine retromarginal teeth. The measurements of legs and leg joints are in Table 1 . TmI $=0.64$. Tibia I-III with one trichobothrium, tibia IV with 2 trichobothria (Fig. $2 \mathrm{e})$. Spination 2-2-2-1, spines on leg I very small and barely distinguishable, about $1 / 3$ of tibia diameter, spines on legs II-IV are stouter. Palp as in Figs. 1a-b, 2d-e, tibia with one dorsal apophysis, it is rounded on the tip, paracymbium three-dimensional, with triangle outgrowth below hooklike tip, base of paracymbium with 4 fine setae, protegulum undeveloped. Suprategulum with subconical mesal apophysis (Ma) suprategular apophysis (Sa) very long, with its apical half making about a $100^{\circ}$ turn. Embolic division Sshaped, embolic part (Em) with sharply pointed

Table 1. The length of legs and leg joints of Uusitaloia wrangeliana sp.n., holotype (in mm).

\begin{tabular}{lcccccc}
\hline Leg $\backslash$ joint & Femur & Patella & Tibia & Metatarsus & Tarsus & Total \\
\hline I & 0.53 & 0.17 & 0.51 & 0.33 & 0.29 & 1.83 \\
II & 0.50 & 0.16 & 0.44 & 0.36 & 0.30 & 1.76 \\
III & 0.46 & 0.16 & 0.36 & 0.34 & 0.30 & 1.62 \\
IV & 0.59 & 0.16 & 0.53 & 0.47 & 0.33 & 2.08 \\
\hline
\end{tabular}




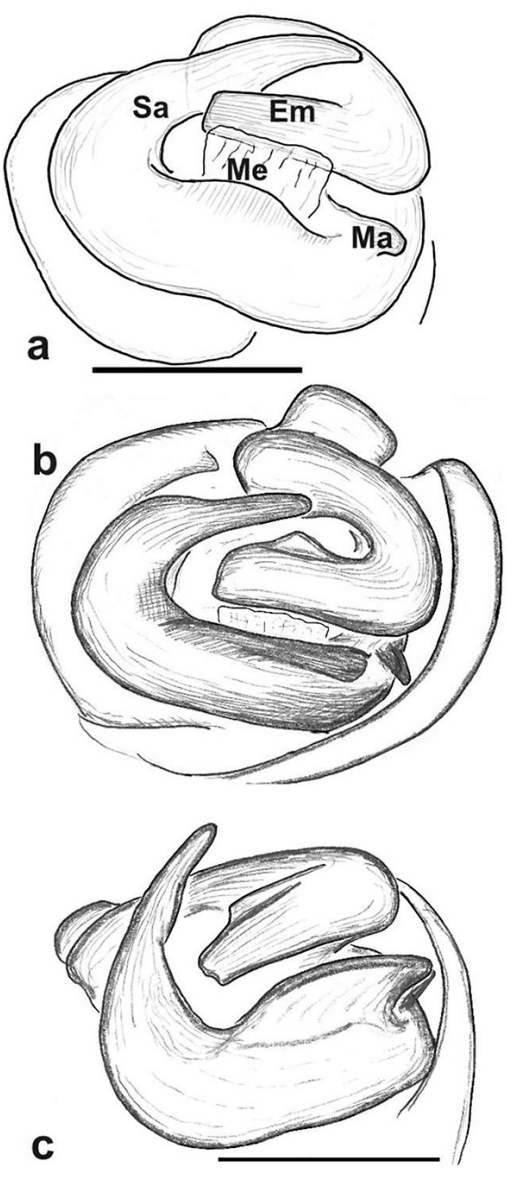

outgrowth (Ea). Embolic membrane wide, poorly visible due to hard sclerotisation of the embolic division and suprategular apophysis.

Female unknown.

Diagnosis. The new species in general appearance resembles very much the type species $U$. transbaicalica and has carapace and palp of the same size. The two species can be separated by the presence of modified hairs on the ocular area in $U$. transbaicalica which are absent in the new species. The new species can also be distinguished by the rounded tip of the tegular apophysis (Fig. 1b) (rectangular in U. transbaicalica, Fig. 1e), and the presence of a spine-like outgrowth of embolus (Figs. 1a, 2d) (no outgrowth in U. transbaicalica, Figs. 2a-c). The two species also slightly differ in the shape of paracymbium.

Biology. The specimens were collected on steppe-like mound.

Distribution. Type locality only (Fig. 3).
Fig. 2. Uusitaloia transbaicalica, holotype $(\mathrm{a}-\mathrm{c})$ and $U$. wrangeliana sp.n., holotype (de). $-a-d$. Terminal part of the bulb, view from above, different turns. e. Habitus of $U$. wrangeliana sp.n., all trichobothria on left legs pointed. Scale $=0.1$ $\mathrm{mm}$. Abbreviations: Ea: embolic apophysis, Em: embolus, Ma: median suprategular apophysis, Me: embolic membrane, Sa: suprae tegular apophysis.

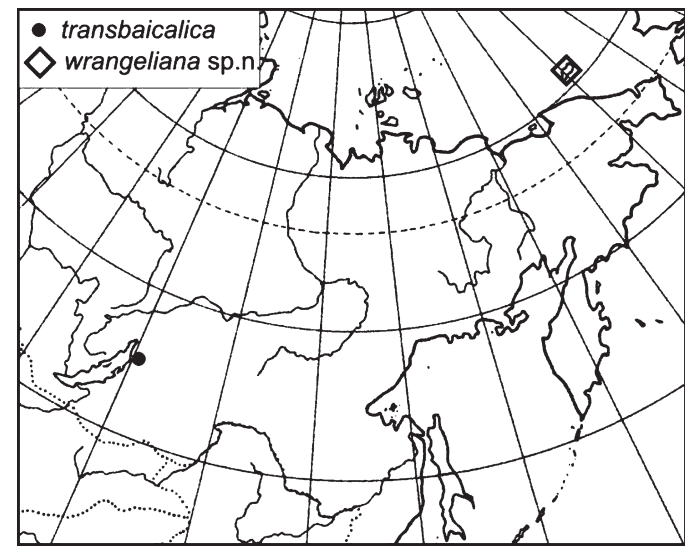

Fig. 3. Type localities of Uusitaloia transbaicalica and U. wrangeliana sp.n.

Etymology. The species name is derived from the type locality. 


\subsection{Uusitaloia transbaicalica Marusik, Koponen \& Danilov, 2001 (Figs. 1c-e, 2a-c)}

U. t. Marusik et al., 2001: 90, f. 39-48 (D今).

Material examined. Holotype male in ZMUT with label "RUSSIA: Buryatia, Barguzin range, Olso River, 54 ${ }^{\circ} 52^{\prime} \mathrm{N}, 110^{\circ} 55^{\prime} \mathrm{E}, 1650$ m, 4 July 1996 (M. Uusitalo)".

Description. Total length 1.53. Carapace length 0.71 , width 0.53 , unmodified, with head slightly elevated above thorax, greyish-brown with darker margins, radial stripes and rhomboid spot in posterior part of cephalic area. Clypeus and eye area covered with short, sparse hairs. Sternum dirty brownish. Abdomen dark grey. Legs yellow. Spination 2-2-2-1, leg I segments: $0.54+0.64+0.37+0.31$. Tm I 0.65. Tm IV absent. Palp as in Figs. 1c-e, 2a-c.

Diagnosis. See under $U$. wrangeliana sp. n.

Distribution. Type locality only (Fig. 3).

\section{Discussion}

In describing the new genus, we (Marusik et al. 2001) overlooked some fine spines on the legs and thus gave the wrong spine-formula $0-1-1-1$. The correct formula is 2-2-2-1. Discovery of the new species did not lead to any significant change of the diagnosis. Clypeus and eye field may or may not be covered by hairs, and the embolus may have an outgrowth. Judging from the conformation of the male palp, this genus belongs to the Savignia group sensu Millidge (1977) due to the elongated suprategular apophysis turned around the tip of embolus (embolic division).

From all members of this group Uusitaloia differs by the position of a trichobothrium on metatarsus I (0.64-0.65) and the spination (2-2-21). All other genera have a trichobothrium at the position between 0.35 and 0.55 and the spination 2-2-1-1. Like Dicymbium, and unlike in other genera of the Savignia group, Uusitaloia lacks a trichobothrium on leg IV. Another unique affinity of this genus is the extremely long suprategular apophysis, which is longer than the embolic division.
Although females in this genus are still unknown, it is possible to expect that the ventral epigynal plate is subdivided in two parts like in others of the Savignia group (Savignia, Araeoncus, Diplocephalus, Dicymbium, etc.).

Judging from the size of disjunction between the two Uusitaloia species (Fig. 3), which indicates larger earlier range of the genus, it is easy to expect that additional species of this genus can be found in mountains of South and Northeastern Siberia. Most of these mountain areas are poorly studied.

Acknowledgements. We wish to express our thanks to Dr. Olga A. Khrulyova (Moscow) who collected the new species, and to Dr. Olga L. Makarova (Moscow), who passed unsorted material to us. This study was supported by INTAS grant Nr 05-1000008-8224.

\section{References}

Khrulyova, O. A. 1987: Invertebrates. Fauna of the Wrangel Island Reserve. - In: Mikhailov, K. G. (ed.), Operative-informative materials: 6-36. Institute of Ecology and Morphology of Animals, Moscow. [In Russian]

Marusik, Yu. M. \& Koponen, S. 2006: Diversity of spiders (Araneae) on Arctic Islands. - Abstracts, 23rd European Colloquium of Arachnology. Sitges, Barcelona 2006: 69.

Marusik, Yu. M., Eskov, K.Yu. \& Kim, J. P. 1992: A checklist of spiders (Aranei) of North East Asia. - Korean Arachnology 8(1/2): 129-158.

Marusik, Yu. M., Koponen, S. \& Danilov, S. N. 2001: Taxonomic and faunistic notes on linyphiids of Transbaikalia and south Siberia. - Bulletin of the British Arachnological Society 12(2): 83-92.

Millidge, A. F. 1977: The conformation of the male palpal organs of linyphiid spiders, and its application to the taxonomic and phylogenetic analysis of the family (Araneae: Linyphiidae). - Bulletin of the British Arachnological Society 4: 1-60.

Platnick, N. I. 2007: The world spider catalog, version 8.0. - American Museum of Natural History. [www document]. URL http://research.amnh.org/entomology/spiders/catalog/index.html (accessed September 2007).

Stishov, M. S. 2004: (Wrangel Island-model of nature and natural anomaly). - Mari Publishing House, Yoshkar-Ola. 596 pp. [In Russian] 